\title{
Announcements
}

On July $4-5,2008$, the ASSOCIATION of BUSINESS HISTORIANS will hold its annual meeting at the University of Birmingham. The theme is "Business History after Chandler." The primary aim of this conference is to provide a forum for reflecting on the contribution of Alfred DuPont Chandler Jr. (1918-2007) to the development of business history. We welcome in particular papers that engage explicitly and constructively with the Chandlerian paradigm, including specific country and firm studies. For more information, please contact:

Francesca Carnevali
Department of Modern History
University of Birmingham
Birmingham B15 2TT
United Kingdom
E-mail: f.carnevali@bham.ac.uk

The 2008 annual meeting of the BUSINESS HISTORY CONFERENCE will be held in Sacramento, California, from April 10 to 12, hosted by the California State University at Sacramento. Its theme is "Expanding Connections for Business History," with the goal of reaching across disciplines and audiences. It will focus on what business history offers to other fields of scholarship, as well as what business historians can learn from other scholarly perspectives. In addition, both the opening plenary and a roundtable will explore how business historians can work with the press to extend their reach into the public and business management arenas. Sessions will highlight research that is comparative, that contextualizes its subjects, or that examines any of the complex interactions that business activities involve. The conference will expand business history's intellectual connections and approaches, broadening its outreach to both scholarly and public audiences.

For more information, including travel grants and other opportunities for graduate students, see our Web site: http://www.thebhc.org/ annmeet/. Please send queries to:

Maggie Levenstein, Program Chair

E-mail: MaggieL@umich.edu

or

Pamela W. Laird, BHC President

E-mail: pamela.laird@cudenver.edu 


\title{
Announcements / 772
}

The HAGLEY MUSEUM and LIBRARY will sponsor "Automobility: A Conference on the 1ooth Anniversary of the Model T," on November 6-7, 2008. The Center for the History of Business, Technology, and Society at the Hagley Museum and Library invites papers that reflect broadly on the impact of motor vehicles in America since 1908. The appearance of Ford's Model T automobile in 1908 ushered in a century during which motorized vehicles spread across the American landscape. Their impact was immense, visible in structures such as roads, bridges, garages, and parking lots, in businesses including service stations and fast-food restaurants, and in altered residential patterns. In addition to cars, other conveyances, such as buses, trucks, mobile homes, fire engines, and motorcycles, as well as vehicles produced for construction and military purposes, reshaped business and commerce, created new industries, and generated endless technological innovations.

As the automobile has been the subject of considerable scholarly work, papers concerning passenger cars should break new ground and address heretofore underexplored questions. Scholarship on other vehicles powered by internal combustion engines is far less developed. We therefore especially encourage papers that consider their business, technological, and commercial dimensions. All papers should be empirically based and historically informed.

Proposals should be no more than 500 words and accompanied by a short curriculum vitae. Deadline for submissions is March 31, 2008. Travel support is available for those presenting papers at the conference. To submit a proposal or to obtain more information, contact:

\author{
Carol Lockman \\ Hagley Museum and Library \\ P.O. Box 3630 \\ Wilmington, DE 19807 \\ Telephone: 302-658-2400, ext. 243 \\ Fax: 302-655-3188 \\ E-mail: clockman@Hagley.org
}

\begin{abstract}
"MONEY, POWER AND PRINT: Interdisciplinary Studies of the Financial Revolution in the British Isles, 1688-1776," is a colloquium that will be held at St. John's, Newfoundland, Canada, from June 26 to 28 , 2008. It will gather scholars from a wide range of disciplines to study the intersections between public finance, politics, and literature during Britain's so-called Financial Revolution. (The term "British" is used loosely to refer to all constituent parts of the United Kingdom and also
\end{abstract}


to Ireland and the colonies. The term "literature" is broadly defined to include newspapers, pamphlets, treatises, novels, plays, and prints.)

The colloquium is an initiative of "Money, Power, and Print," an association of scholars interested in an interdisciplinary approach to the Financial Revolution. Further details are available at www.money powerandprint.org. For more information, please contact one of the organizers:

Chris Fauske

School of Arts \& Sciences

Salem State College

352 Lafayette St.

Salem, MA 01970-5353

E-mail: christopher.fauske@salemstate.edu

or

Rick Kleer

Department of Economics

University of Regina

3737 Wascana Parkway

Regina, Saskatchewan

CANADA S4S OA2

E-mail: richard.kleer@uregina.ca

or

Ivar McGrath

School of Humanities \& Histories

Trinity College Dublin

College Green

Dublin 2

IRELAND

E-mail: mcgratci@tcd.ie

A conference entitled "ANDRE GUNDER FRANK'S LEGACY OF CRITICAL SOCLAL SCIENCE" will be held at the University of Pittsburgh, David Lawrence Hall, April 11-13, 2008. This is to be a major international conference honoring the life and work of André Gunder Frank, a pioneer in global analysis in history and social science. He died at age seventy-six in April 2005, after more than fifty years of prodigious output in economic and social analysis of global interaction. The conference will gather the major scholars with whom Frank has worked and debated in order to remember his contribution, to take stock, and to identify future directions of study. It will provide encouragement for 
scholars of all ages and disciplines to take the next steps in debating and documenting these critical social issues. The conference will emphasize but will not be limited to six topical areas of Gunder Frank's writings: (1) underdevelopment and dependency in Latin America; (2) world accumulation and world system; (3) the five-thousand-year world system; (4) East Asia in the world economy; (5) social movements; and (6) contemporary political and economic analysis.

Giovanni Arrighi, John Beverley, Christopher Chase-Dunn, Barry K. Gills, Kenneth Pomeranz, Anibal Quijano, Kaoru Sugihara, and Immanuel Wallerstein will be among the featured speakers.

For all conference issues, contact the conference coordinator, Robert Fagley at AGFRANK@pitt.edu, or go to the conference Web site: http://www.worldhistorynetwork.org/dev/AGFRANK-conference.htm.

The editors of the Business History Review would like to thank the scholars who assisted the journal by serving as manuscript readers. The people listed below are those who, in addition to the members of the Editorial Advisory Board, performed this task in 2007:

Atsushi Akera, Rensselaer Polytechnic Institute

Rolv Petter Amdam, BI Norwegian School of Management

Thomas Augst, University of Minnesota

Ralph Austen, University of Chicago

Theo Balderston, University of Manchester

Jim Bamberg, University of Cambridge

Regina Blaszczyk, Hagley Museum and Library

Gordon Boyce, University of Newcastle

Marcelo Bucheli, University of Illinois at Urbana-Champaign

Glenn Bugos, Moment $L L C$

Peter Coclanis, University of North Carolina at Chapel Hill

Priscilla Connolly, Universidad Autónoma

Metropolitana-Azcapotzalco

James W. Cortada, IBM

Mila Davids, Technical University Eindhoven

Gerardo della Paolera, American University of Paris

Greg Downey, University of Wisconsin-Madison

Ben Forster, University of Western Ontario

Andres Gallo, University of North Florida

Pascale Ghazaleh, American University in Cairo

Andrew Godley, University of Reading

Aurora Gomez-Galvarriato, CIDE 
Hugh Gorman, Michigan Technological University

Stephen Haber, Stanford University

Barbara Hahn, Texas Tech University

Thomas Haigh, University of Wisconsin, Milwaukee

Shane Hamilton, University of Georgia

Anne Hanley, Northern Illinois University

William Hausman, College of William \& Mary

Peter Hayes, Northwestern University

Philip Hoffman, California Institute of Technology

David Hogan, Heidelberg College

Harold James, Princeton University

Thomas Kaiserfeld, Royal Institute of Technology

Matthias Kipping, York University

Chris Kobrak, ESCP-EAP

Elisabeth Köll, Case Western Reserve University

William Lazonick, University of Massachusetts, Lowell

C.M. Lewis, London School of Economics

Andrea Lluch, Harvard University

Brian Luskey, University of Northern Colorado

Michael Lynskey, Hitotsubashi University

Cathy Matson, University of Delaware

Christopher McKenna, Georgetown University

Ranald Michie, University of Durham

Rory Miller, University of Liverpool

Michael Miller, University of Miami

Jamie Monson, Carleton College

Julio Moreno, University of San Francisco

Sharon Ann Murphy, Providence College

Aldo Musacchio, Harvard University

Daniel Nelson, University of Akron

Lucy Newton, University of Reading

Mary O'Sullivan, University of Pennsylvania

Gregory Patmore, University of Sydney

Robin Pearson, University of Hull

Ian Phimister, University of Sheffield

Ismail Rashid, Vassar College

Andrés Regalsky, Universidad Torcuato Di Tella

Fernando Rocchi, Universidad Torcuato Di Tella

Paul Sabin, Environmental Leadership Program

Jonas Scherner, University of Mannheim

Harm Schroeter, University of Bergen

David Sicilia, University of Maryland

Richard Sicotte, University of Vermont 


\section{Announcements / 776}

J. Pablo Silva, Grinnell College

Marc Stern, Bentley College

Ray Stokes, University of Glasgow

Jeffrey Sturchio, Merck \& Co., Inc.

William Summerhill, University of California, Los Angeles

Rick Szostak, European University Institute

Joseph E. Taylor III, Simon Fraser University

Adam Tooze, University of Cambridge

Gail Triner, Rutgers University

Gunnar Trumbull, Harvard University

Robert W. Vivian, University of the Witwatersrand

Richard Walter, Washington University, St. Louis

Wyatt Wells, Auburn University, Montgomery

Timothy Whisler, Saint Francis University

Eugene N. White, Rutgers University

Robert Wright, New York University

Madeleine Zelin, Columbia University 